\title{
Dairy cows experience selective reduction of the hepatic growth hormone receptor during the periparturient period
}

\author{
Jin Wook Kim, Robert P Rhoads, Stephanie S Block, \\ Thomas R Overton, Stuart J Frank ${ }^{\mathbf{1}}$ and Yves R Boisclair \\ Department of Animal Science, Cornell University, Ithaca, New York 14853-4801, USA \\ ${ }^{1}$ Department of Medicine, Division of Endocrinology and Metabolism, and Department of Cell Biology and Physiology, University of Alabama at Birmingham, \\ and Veterans Affairs Medical Center, Birmingham, Alabama 35294, USA \\ (Requests for offprints should be addressed to Yves R Boisclair, 259 Morrison Hall, Department of Animal Science, Cornell University, Ithaca, NY 14853-4801, \\ USA; Email: yrb1@cornell.edu)
}

\begin{abstract}
At parturition, dairy cows experience a $70 \%$ reduction in plasma IGF-I. This reduction coincides with decreased abundance of GHR1A, the liver-specific transcript of the growth hormone receptor (GHR) gene, suggesting impaired growth hormone-dependent synthesis of IGF-I. It is not immediately obvious that the periparturient reduction in GHR1A is sufficient to reduce hepatic GHR abundance. This is because $\sim 50 \%$ of total GHR mRNA abundance in prepartum liver is accounted for by ubiquitously expressed transcripts which remain collectively unchanged at parturition. In addition, the possibility that parturition alters GHR expression in other growth hormone target tissue has not been examined. To address these questions, we measured GHR gene expression and GHR protein in liver and skeletal muscle of four dairy cows on days $-35,+3$ and +56 (relative to
\end{abstract}

parturition on day 0). Hepatic GHR abundance and GHR1A transcripts were lower on day +3 than on day -35 and returned to late pregnancy value by day +56 . Additional studies in two other groups of cows indicated that the hepatic levels of the GHR protein recovered substantially within 10 days after parturition. These changes occurred without variation in the abundance of HNF4, a liver-enriched transcription factor activating the promoter responsible for GHR1A synthesis. In contrast to liver, levels of GHR gene expression and GHR protein were identical on days $-35,+3$ and +56 in skeletal muscle. These data suggest a role for the GHR in regulating tissue-specific changes in growth hormone responsiveness in periparturient dairy cows.

Journal of Endocrinology (2004) 181, 281-290

\section{Introduction}

In dairy cattle, the onset of copious milk secretion at parturition occurs in the absence of an adequate compensatory increase in energy intake (Bell 1995, Block et al. 2001). As a result, the first few weeks of lactation are characterized by an intense energy deficit (Bell 1995, Block et al. 2001). Plasma IGF-I, which is produced predominantly in liver in response to growth hormone (GH) (Le Roith et al. 2001), is reduced by approximately $70 \%$ at parturition in lactating dairy cows (Kobayashi et al. 1999, Block et al. 2001). Recently, Kobayashi et al. (1999) suggested that the periparturient fall in plasma IGF-I was the consequence of decreased GH receptor (GHR) abundance in liver. This suggestion was based on coincidental reductions in the abundance of IGF-I mRNA and GHR1A mRNA, the liver-specific GHR transcript (Kobayashi et al. 1999). It is unclear, however, whether the periparturient reduction in GHR1A expression is sufficient to cause a reduction in the GHR protein. This is because the other classes of GHR transcripts account for $\sim 50 \%$ of total GHR abundance in well-fed bovine liver (Jiang \& Lucy 2001a), and their collective abundance is not reduced at parturition (Kobayashi et al. 1999).

In addition to its stimulation of IGF-I synthesis, GH exerts major effects on the fate of glucose, proteins and lipids (Etherton \& Bauman 1998, Herrington \& Carter-Su 2001, Okada \& Kopchick 2001). For example, exogenous administration of $\mathrm{GH}$ to dairy cows increases the oxidative use of lipids at the expense of glucose (Bauman et al. 1988). A major portion of this organismal effect represents the ability of $\mathrm{GH}$ to attenuate glucose uptake by skeletal muscle (Sechen et al. 1990, Boisclair et al. 1994). This effect of $\mathrm{GH}$ has been assumed to increase at parturition when the concentration of plasma GH is naturally elevated (Bell 1995, Bauman 2000, Block et al. 2001). However, we do not know whether parturition regulates GHR expression in skeletal muscle in a manner that would allow such effects of $\mathrm{GH}$. 
Our first objective was to determine whether reduced GHR1A expression in periparturient dairy cows was associated with a reduction in hepatic GHR protein abundance. Because GHR1A is produced by a promoter regulated by the liver-enriched transcription factor HNF4 (Jiang \& Lucy 2001b), we also examined the possibility that the periparturient drop of GHR1A mRNA was associated with reduced HNF4 abundance. A second major objective was to determine whether parturition altered the abundance of the GHR in skeletal muscle. Our results show that hepatic GHR abundance is reduced at parturition, but recovers significantly within 10 days after parturition. In contrast, GHR abundance remains constant during the periparturient period in skeletal muscle.

\section{Materials and Methods}

\section{Animals and design}

All experimental procedures were conducted with the approval of the Cornell University Institutional Animal Care and Use Committee. Multiparous Holstein cows (age $3.8 \pm 0.7$ years; parity number $1.9 \pm 0.5$ ) were housed in individual stalls, except around the time of parturition, when they were moved to individual maternity pens. The facility was lighted between 0600 and $2300 \mathrm{~h}$.

Periparturient period study Changes in GHR expression and abundance were studied in four cows used previously to describe changes in plasma leptin in the period between 35 days prepartum and 56 days postpartum (days -35 to +56 relative parturition) (Block et al. 2001). Briefly, they were fed a total mixed ration (TMR) ad libitum once daily at $1100 \mathrm{~h}$ according to recommended feeding standards (NRC 2001). The TMR contained 1.45 Mcal of net energy of lactation $\left(\mathrm{NE}_{\mathrm{L}}\right)$ and $125 \mathrm{~g}$ crude protein $(\mathrm{CP})$ per kg of dry matter (DM) between days -35 and $-21,1.63 \mathrm{Mcal} \mathrm{NE}_{\mathrm{L}}$ and $143 \mathrm{~g} \mathrm{CP}$ per $\mathrm{kg} \mathrm{DM}$ between days -21 and parturition, and $1.76 \mathrm{Mcal} \mathrm{NE}_{\mathrm{L}}$ and $183 \mathrm{~g} \mathrm{CP}$ per kg DM during lactation (NRC 2001). Cows were milked thrice daily at 0900, 1600 and $2300 \mathrm{~h}$.

Blood samples were collected between 0900 and $1000 \mathrm{~h}$ on days $-35,+3$ and +56 by coccygeal venipuncture. Plasma was prepared immediately and frozen at $-20{ }^{\circ} \mathrm{C}$ until analyzed. After blood sampling on days $-35,+3$ and +56 , biopsies of liver and semitendinosus muscle were done by previously described methods (Moloney et al. 1998, Bernal-Santos et al. 2003). Biopsies were snapfrozen in liquid nitrogen and stored at $-80{ }^{\circ} \mathrm{C}$.

Postparturient period studies For examination of the recovery kinetics of hepatic GHR after parturition, two additional groups of cows were used. In the first group of six cows, liver biopsies were obtained on days $+1,+21$ and +63 (relative to parturition). In the second group of eight cows, liver biopsies were obtained on days $+1,+10$ and +21 . Both group of cows were fed ad libitum levels of lactating TMRs averaging $1.72 \mathrm{Mcal} \mathrm{NE}_{\mathrm{L}}$ and $170 \mathrm{~g} \mathrm{CP}$ per $\mathrm{kg} \mathrm{DM}$, and milked thrice daily. Liver biopsies were stored at $-80{ }^{\circ} \mathrm{C}$ until analyzed.

\section{Whole-body energetics}

Dry matter intake and milk yield were measured daily. Aliquots of milk were collected daily (periparturient study) or weekly (postparturient studies) and analyzed for proteins, fat and lactose content by infrared analysis (Dairy One Cooperative, Ithaca, NY, USA). Energy content of milk and feeds was estimated from chemical composition (NRC 2001). Every week, body weights were recorded at a standard time. These data were used to calculate individual estimates of net energy balance on a weekly basis (Block et al. 2001).

\section{Analysis of hormones}

Plasma IGF-I, insulin and GH were measured by previously described double-antibody RIA (Cohick et al. 1989, Block et al. 2001). For each RIA, bovine proteins were used for iodination and standards (recombinant IGF-I, lot GST-3 (Monsanto, St Louis, MO, USA); rbST, lot 12-77-001 (Upjohn Co., Kalamazoo, MI, USA); and purified insulin, lot 615-70N-80 (Lilly Research Laboratories, Indianapolis, IN, USA)). The primary antibodies against IGF-I (rabbit anti-human IGF-I, lot AFP4892898) and GH (rabbit anti-oGH-2) were obtained from the National Hormone and Pituitary Program (Bethesda, MD, USA). The primary antibody for the insulin RIA was purchased from Linco Research (guinea pig anti-porcine insulin serum, lot 122-845-P, St Charles, MO, USA). Secondary antibodies used were caprine anti-rabbit IgG for the IGF-I RIA (lot 12515, Biotech Source, Franklin, MA, USA), ovine anti-rabbit IgG for the GH RIA (kind gift of W R Butler, Cornell University, USA) and goat anti-guinea pig $\operatorname{IgG}$ for the insulin RIA (lot GP 2020, Linco Research, St Charles, MO, USA). Inter- and intra-assay coefficients of variation for all assays averaged less than $8 \%$ and $9 \%$ respectively.

\section{Analysis of gene expression}

Total RNA was extracted from liver and skeletal muscle by a modification of the guanidium thiocyanate-phenolchloroform method (Rhoads et al. 2000). Glycogen was removed from hepatic total RNA by affinity chromatography (RNeasy, Qiagen). The concentration of total RNA was determined by absorbance at $260 \mathrm{~nm}$, and its quality was verified by staining formaldehyde agarose gel with Sybr Green II (Molecular Probes, Eugene, OR, USA).

Hepatic expression of the IGF-I and GHR genes was measured by specific ribonuclease protection assay (RPA). Partial DNA fragments corresponding to bovine IGF-I 
and GHR1A mRNA (Kobayashi et al. 1999) were subcloned in the plasmid Lit 29 (New England Biolabs) for the generation of antisense RNA using $\left[{ }^{32} \mathrm{P}\right] \mathrm{UTP}$ and T7 polymerase (Maxiscript, Ambion, Austin, TX, USA). Antisense RNA was hybridized with total RNA $(10 \mu \mathrm{g})$ using a commercial kit (RPA III, Ambion). Each RPA was performed in the presence of a 10-fold molar excess of a low-specific activity $18 \mathrm{~S}$ riboprobe generated from an $18 \mathrm{~S}$ DNA template (Ambion). The IGF-I probe yields a single signal of $200 \mathrm{bp}$ [137 nt from exon 3 and $63 \mathrm{nt}$ from exon 4] (Kobayashi et al. 1999). The GHR1A probe contains $191 \mathrm{bp}$ corresponding to exon $1 \mathrm{~A}$ and $121 \mathrm{bp}$ corresponding to exons 2 and 3 (Kobayashi et al. 1999). Therefore, it yields a signal of $312 \mathrm{bp}$ for the GHR1A transcript and a signal of $121 \mathrm{bp}$ corresponding to the sum of all other GHR transcripts $\left(\mathrm{GHR}_{\text {other }}\right)$. Signals were quantified by phosphorimaging and normalized to the $18 \mathrm{~S}$ signal.

\section{Cell culture experiments}

Wild-type mouse L cells were cultured in Dulbecco's modified Eagle's medium plus 10\% (v/v) fetal calf serum and gentamicin $(50 \mu \mathrm{g} / \mathrm{ml}$, Gibco, Carlsbad, CA, USA). Mouse L cells stably expressing the bovine GHR (Wang et al. 1994) were grown as above with the addition of $400 \mu \mathrm{g} / \mathrm{ml}$ of the selective agent G418 (Gibco). Cells were washed twice with ice-cold PBS supplemented with $0.4 \mathrm{mM} \mathrm{Na} \mathrm{VO}_{4}$, and solubilized in lysis buffer (10 mM Tris, $\mathrm{pH} 7 \cdot 6,1 \%$ Triton X-100, 1 mM EGTA, $150 \mathrm{mM} \mathrm{NaCl}, 1 \mathrm{mM} \mathrm{Na} \mathrm{VO}_{4}, 1 \mathrm{mM} \mathrm{Na}$ pyrophosphate, $10 \mathrm{mM} \mathrm{NaF}, 1 \mathrm{mM}$ EDTA, $1 \mathrm{mM}$ PMSF, $10 \mu \mathrm{g} /$ $\mathrm{ml}$ aprotinin and $10 \mu \mathrm{g} / \mathrm{ml}$ leupeptin). In some experiments, cells were deprived of serum for $16 \mathrm{~h}$, and lysed before and after addition of $100 \mathrm{ng} / \mathrm{ml}$ of bovine $\mathrm{GH}$ (Monsanto) (see legend of Fig. 3 for times).

The human embryonic kidney cell line 293 was grown in minimal Eagle's medium supplemented with $10 \%$ fetal calf serum. At $24 \mathrm{~h}$ before transfection, cells were plated at a density of $2 \times 10^{6}$ cells $/ 60 \mathrm{~mm}$ dish. They were transfected with $3.3 \mu \mathrm{g}$ of plasmid pcDNA3.1-rHNF4 $\alpha$ encoding rat HNF4 $\alpha$ by the calcium phosphate method (Boisclair et al. 1993). At $48 \mathrm{~h}$ after transfection, cells were washed twice with PBS, and solubilized in lysis buffer.

\section{Preparation of cellular extracts from liver and skeletal muscle}

Frozen tissues $(500 \mathrm{mg})$ were homogenized using a polytron (20000 RPM, $1 \mathrm{~min}$ ) in $2 \mathrm{ml}$ of lysis buffer. Homogenates were clarified by two sequential centrifugations $\left(10000 \mathrm{~g}\right.$ for $20 \mathrm{~min}$ at $\left.4^{\circ} \mathrm{C}\right)$, and supernatants were stored at $-80{ }^{\circ} \mathrm{C}$.

A preparation enriched in membrane protein, such as those used in GH radioreceptor assays, was also prepared (Elsasser et al. 1998). Briefly, $500 \mathrm{mg}$ of frozen liver tissue was homogenized in $5 \mathrm{ml}$ of sucrose buffer $(50 \mathrm{mM}$ Tris, pH 7·6, $250 \mathrm{mM}$ sucrose, $5 \mathrm{mM}$ EGTA, $150 \mathrm{mM} \mathrm{NaCl}$,
$1 \mathrm{mM} \quad \mathrm{Na}_{3} \mathrm{VO}_{4}, 1 \mathrm{mM} \quad \mathrm{Na}$ pyrophosphate, $5 \mathrm{mM}$ $\mathrm{NaF}, 1 \mathrm{mM}$ PMSF, $10 \mu \mathrm{g} / \mathrm{ml}$ aprotinin and $10 \mu \mathrm{g} / \mathrm{ml}$ leupeptin). After clarification $\left(1000 \mathrm{~g}\right.$ for $5 \mathrm{~min}$ at $\left.4{ }^{\circ} \mathrm{C}\right)$, homogenates were centrifuged $(100000 \mathrm{~g}$ for $60 \mathrm{~min}$ at $4{ }^{\circ} \mathrm{C}$ ). The pellet was rocked overnight at $4{ }^{\circ} \mathrm{C}$ in lysis buffer. Unsuspended materials were removed by centrifugation $\left(12000 \mathrm{~g}\right.$ for $10 \mathrm{~min}$ at $4^{\circ} \mathrm{C}$ ), and supernatants were stored at $-80{ }^{\circ} \mathrm{C}$.

\section{Western immunoblotting and immunoprecipitation}

Cellular proteins were electrophoresed on 10\% SDSpolyacrylamide gels (see Figure legends for amounts), and transferred onto nitrocellulose membranes (Schleider and Schuell, Keene, NH, USA). The membranes were incubated for $1 \mathrm{~h}$ at room temperature in blocking solution (Tris-buffered saline with Tween-20 (TBST; 0.05 M Tris, $\mathrm{pH} 7 \cdot 4,0 \cdot 2 \mathrm{M} \mathrm{NaCl}$ and $0 \cdot 1 \%$ Tween-20) containing $5 \% \mathrm{w} / \mathrm{v}$ nonfat dried skimmed milk). Membranes were incubated with primary antibodies raised against the human GHR (rabbit anti-GHR cyt-AL47, raised against a bacterially expressed, N-terminally His-tagged fusion protein incorporating GHR residues 271-620 (Zhang et al. 2001)), HNF4 (rabbit anti-human HNF4, Geneka Biotechnology, Carlsbad, CA, USA) and Sp1 (rabbit anti-rat Sp1, Santa Cruz Biotechnology, Santa Cruz, CA, USA). Primary antibodies were diluted in blocking solution (GHR and HNF-4, 1:1000; Sp1, 1:2000). Following incubation, membranes were washed five times $(5 \mathrm{~min}$ each) in TBST and then incubated with the secondary antibody (goat anti-rabbit IgG-horseradish peroxidase, KPL, Gaithersburg, MD, USA) at 1:5000 dilution in blocking solution for $1 \mathrm{~h}$ at room temperature. The membranes were washed as above and incubated with LumiGLO Western blot chemiluminescence (KPL). Chemiluminescence was detected by exposure to film. Signals were analyzed by densitometric scanning and NIH Image 1.63 software.

For immunoprecipitation, mouse L cells lysates $(200 \mu \mathrm{g})$ were incubated $\left(4{ }^{\circ} \mathrm{C}\right.$ for $2 \mathrm{~h}$ ) with the GHR antibody (1:500 dilution) in lysis buffer. The immune complexes were collected on protein A agarose (50 $\mu \mathrm{l}$, Gibco) for $2 \mathrm{~h}$ at $4{ }^{\circ} \mathrm{C}$. The beads were washed thrice in lysis buffer and boiled for $5 \mathrm{~min}$ under reducing conditions in $20 \mu \mathrm{l}$ Laemmli loading buffer. Eluted proteins were separated by SDS-PAGE and blotted onto nitrocellulose membranes. The membranes were incubated with antiphosphotyrosine antibody (4G10, 1:2000 dilution, Upstate Inc., Lake Placid, NY, USA) in TBST supplemented with bovine serum albumin $(2 \% \mathrm{w} / \mathrm{v})$, or GHR antibody $(1: 2000$ dilution) in blocking solution. Signals were developed by chemiluminescence and analyzed as described above.

\section{Statistical analysis}

Data were analyzed by a repeated measure model using the SAS statistical package (SAS Institute, Cary, NC, 
Table 1 Changes in net energy balance and plasma hormones during the periparturient period

\begin{tabular}{|c|c|c|c|c|}
\hline & \multicolumn{3}{|c|}{ Day relative to paturition } & \multirow{2}{*}{$\begin{array}{l}\text { Pooled } \\
\text { SE }\end{array}$} \\
\hline & -35 & +3 & +56 & \\
\hline $\begin{array}{l}\text { Variable } \\
\text { Net energy balance, Mcal/day }\end{array}$ & $7 \cdot 7^{\mathrm{a}}$ & $-14 \cdot 4^{b}$ & $-0 \cdot 1^{\mathrm{a}}$ & $3 \cdot 2$ \\
\hline $\begin{array}{l}\text { Plasma hormones } \\
\text { IGF-l, ng/ml } \\
\text { Growth hormone, ng/ml } \\
\text { Insulin }{ }^{1}, \mathrm{ng} / \mathrm{ml}\end{array}$ & $\begin{array}{l}95^{\mathrm{a}} \\
4 \cdot 3^{\mathrm{a}} \\
0 \cdot 8^{\mathrm{a}}\end{array}$ & $\begin{array}{l}29^{b} \\
8 \cdot 2^{b} \\
0 \cdot 3^{b}\end{array}$ & $\begin{array}{l}36^{\mathrm{b}} \\
8 \cdot 5^{\mathrm{b}} \\
0 \cdot 8^{\mathrm{a}}\end{array}$ & $\begin{array}{c}11 \\
0 \cdot 8 \\
0 \cdot 1\end{array}$ \\
\hline
\end{tabular}

Four multiparous dairy cows were studied during the period between day 35 prepartum and day 56 postpartum (day -35 to +56 relative to parturition).

Means with different superscript letters differ at $P<0.05$.

${ }^{1}$ In the case of insulin, prepartum values were obtained on day -22 instead of -35 .

USA). The mixed model accounted for time as the fixed effect (days $-35,+3$ and +56 in the periparturient study; days $+1,+21$ and +56 or $+1,+10$ and +21 in the postparturient studies) and animal as the random effect. The multiple comparisons were performed using the Fisher's protected LSD test. For the main effects, statistical significance was set at the $5 \%$ level $(P<0 \cdot 05)$.

\section{Results}

Onset of lactation is associated with decreased hepatic abundance of IGF-I and GHR1A $m R N A$

The plasma concentration of IGF-I declined by $65 \%$ between late pregnancy and day +3 (Table $1, P<0 \cdot 05$ ). The periparturient drop in plasma IGF-I was associated with increased plasma $\mathrm{GH}$ and decreased plasma insulin, and with the onset of a marked energy deficit $(P<0 \cdot 05)$. To determine whether the postparturient fall in plasma IGF-I represented a change in liver synthesis, biopsies were analyzed for IGF-I mRNA. Hepatic levels of IGF-I
mRNA were lower on day +3 than on day -35 (Fig. 1, $P<0 \cdot 05)$. These data indicate that reduced IGF-I gene expression in liver is partly responsible for the fall of plasma IGF-I around the time of parturition. In addition, hepatic expression, but not plasma IGF-I, returned to prepartum values on day +56 (Fig. 1 and Table 1).

Next, we measured the expression of the GHR with a GHR1A riboprobe. As shown in Fig. 2, GHR1A mRNA changed in a manner identical to IGF-I mRNA, with reduced expression on day $+3(P<0 \cdot 05)$, and recovery by day +56 . The abundance of $\mathrm{GHR}_{\text {other }}$ signal, representing the other GHR transcripts, did not change. These results suggest a model whereby lower GHR abundance at parturition contributes to the reduction of plasma IGF-I by attenuating GH-dependent synthesis of IGF-I.

\section{Onset of lactation is associated with decreased hepatic GHR abundance}

To determine whether the periparturient reduction in GHR1A is sufficient to cause a reduction in GHR abundance, we measured GHR abundance with a
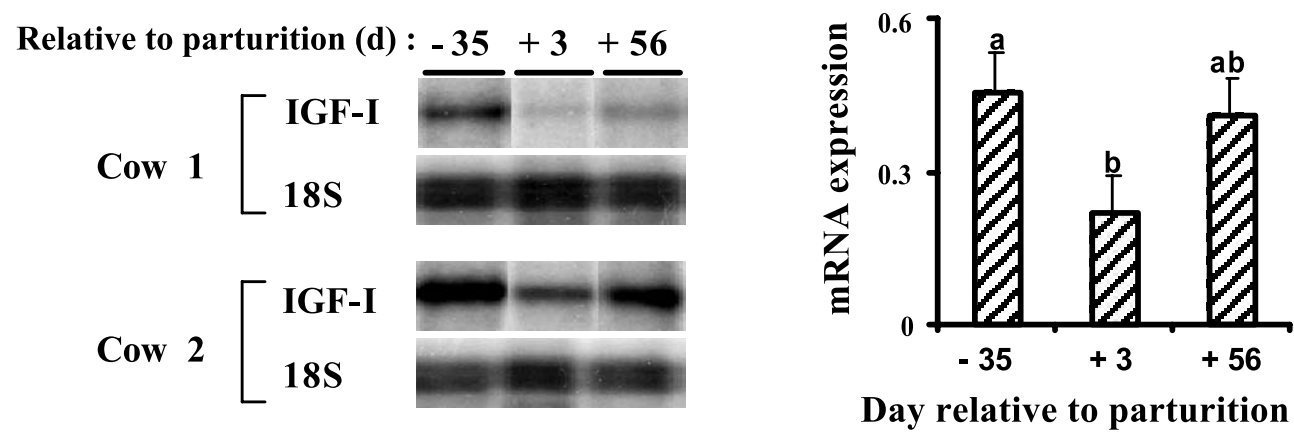

Figure 1 Hepatic IGF-I gene expression during the periparturient period. Four multiparous dairy cows were studied on days $-35,+3$ and +56 (relative to parturition on day 0 ). Left panel: abundance of IGF-I mRNA was measured in $10 \mu \mathrm{g}$ of total RNA by RPA analysis. Data from two representative cows are shown. Right panel: bars represent means \pm S.E. of the IGF-I signal normalized to the $18 \mathrm{~S}$ signal. Bars with different letters differ at $P<0.05$. 


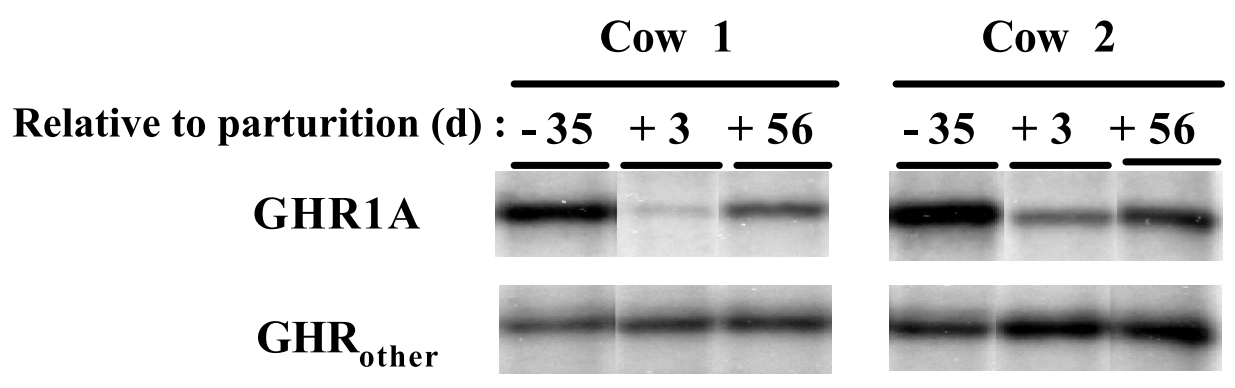

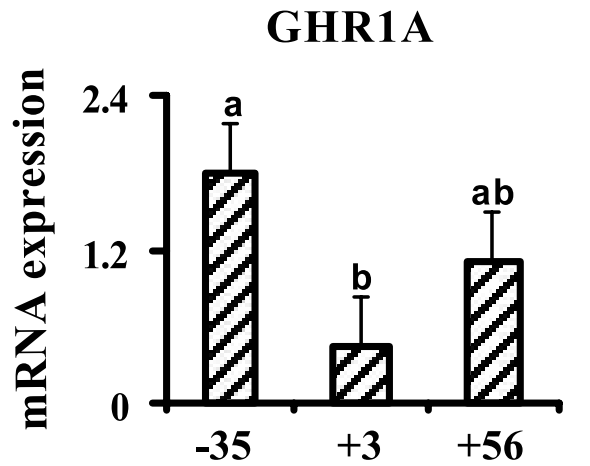

Day relative to parturition

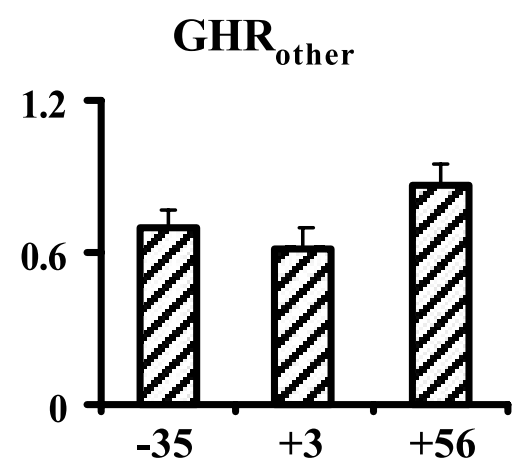

Day relative to parturition

Figure 2 Hepatic GHR gene expression during the periparturient period. Four multiparous dairy cows were studied on days $-35,+3$ and +56 (relative to parturition on day 0 ). Top panel: GHR expression was analyzed by RPA with a GHR1A riboprobe, yielding a 312 bp GHR1A signal, and a 121 bp signal representing all other GHR transcripts $\left(\mathrm{GHR}_{\text {other }}\right)$. Data from two representative cows are shown. Bottom panel: Bars represent means \pm S.E. of the GHR signal normalized to the $18 \mathrm{~S}$ signal (shown in Fig. 1). Bars with different letters differ at $P<0 \cdot 05$.

Western immunoblotting assay based on antibodies raised against the human receptor (Zhang et al. 2001). For validation of this assay, total cellular extracts were prepared from WT mouse L cells or L cells stably transfected with a vector encoding the bovine GHR cDNA, and resolved by SDS-PAGE. In immunoblotting analysis, the GHR antibodies detected bands of $\sim 110$ and $140 \mathrm{kDa}$ only in the cells expressing the bovine GHR (Fig. 3A). Their size was consistent with the precursor and mature forms of the receptor, as shown previously in GHR-expressing cells and tissues of other species (Yi et al. 1996, Beauloye et al. 2002, Wang et al. 2002). Of these two bands, only the upper band was tyrosine-phosphorylated in response to $\mathrm{GH}$ (Fig 3A), confirming its identity with the mature form of the bovine GHR (Yi et al. 1996, Beauloye et al. 2002, Wang et al. 2002).

Bands of $\sim 110$ and $140 \mathrm{kDa}$ were also detected in cellular extracts prepared from bovine liver (Fig. 3B). Abundance of both bands was reduced at day +3 of lactation $(P<0 \cdot 05)$, but returned to precalving levels by day
+56 of lactation. Similar changes were observed when abundance of the GHR was assayed in a membrane preparation such as those used for conventional radioreceptor assays (Fig. 3B). We conclude that periparturient dairy cows have depressed levels of the GHR in liver. This depression and subsequent recovery of the GHR are associated with similar changes in GHR1A abundance.

Next, we determined how long the GHR reduction persisted after parturition. Liver biopsies were taken from mature dairy cows on days $+1,+21$ and +63 of lactation. Hepatic abundance of the GHR was lower on day +1 than on day +21 (Fig. 4A, $P<0 \cdot 05$ ), but similar on days +21 and +63 . The timing of the GHR recovery was further defined by analyzing liver biopsies obtained on days $+1,+10$ and +21 from a second group of cows. GHR abundance was already higher on day +10 than on day +1 (Fig. 4B, $P<0 \cdot 05$ ), but did not differ between days +10 and +21 . The recovery on day +10 occurred despite the persistence of a marked net energy deficit $(-12$ $\mathrm{Mcal} /$ day). Therefore, we conclude that a significant 
(A)

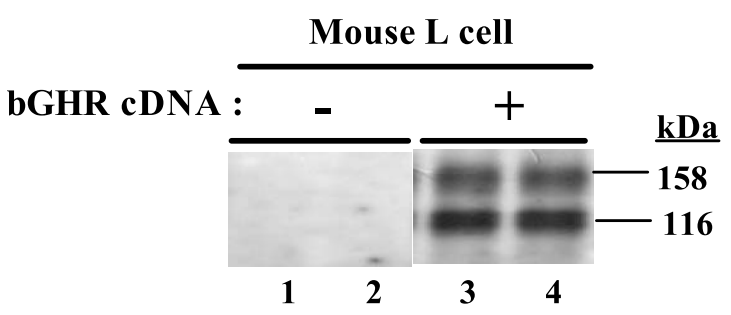

(B)

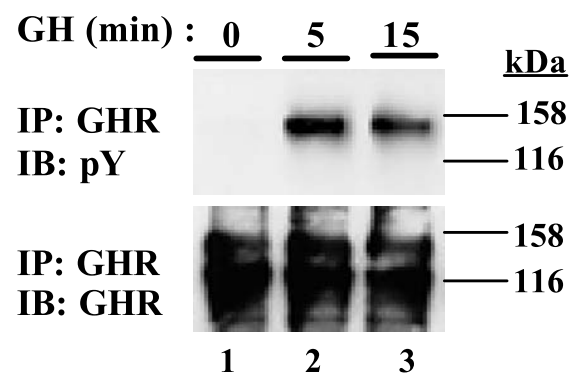

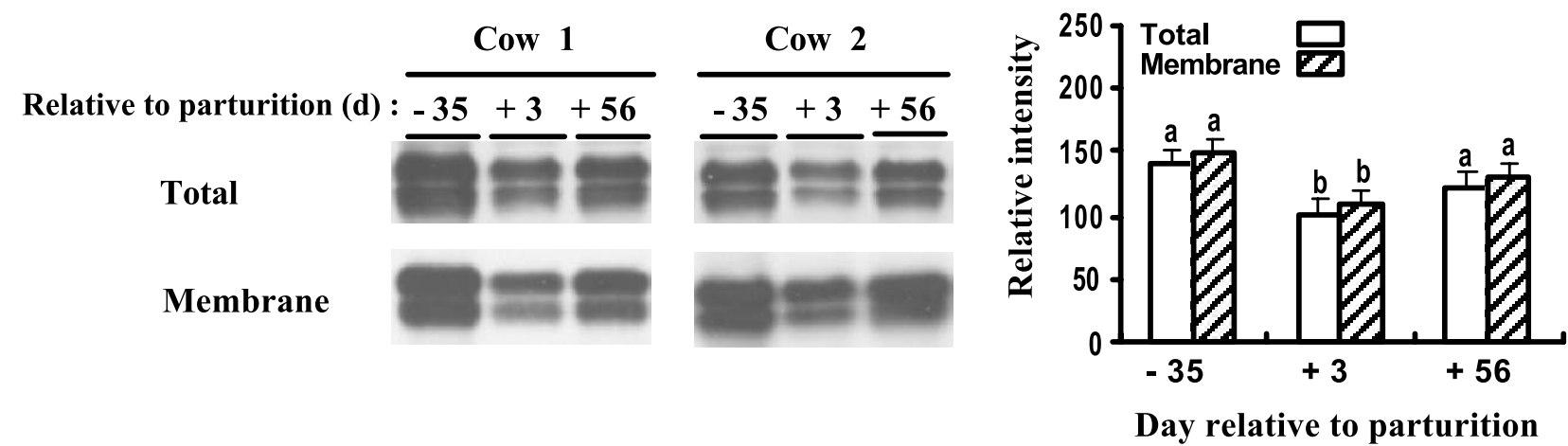

Figure 3 Analysis of the bGHR. (A) Anti-human GHR antibody detects the bovine GHR in Western immunoblotting assay. Left panel: total protein lysates were prepared from WT mouse L cells $(-)$ or mouse L cells transfected with the bGHR cDNA (+). Right panel: total protein lysates were prepared from mouse L cells expressing the bovine GHR immediately before ( 0 min) or 5 and 15 min after treatment with bGH $(100 \mathrm{ng} / \mathrm{ml})$. Total protein lysates $(200 \mu \mathrm{g})$ were immunoprecipitated with anti-human GHR antibody (IP:GHR). Immune complexes were analyzed by SDS-PAGE and detected with the antiphosphotyrosine antibody (4G10, IB:pY) or with anti-human GHR antibody (IB:GHR). The position of protein MW markers is shown on the right of each panel. (B) Hepatic abundance of the bGHR during the periparturient period. Four multiparous dairy cows were studied on days $-35,+3$ and +56 (relative to parturition on day 0 ). Left panel: total cellular proteins (total, $35 \mu \mathrm{g}$ ) or membrane proteins (membrane, $15 \mu \mathrm{g}$ ) were analyzed by Western immunoblotting for the abundance of the GHR. Data from two representative cows are shown. Right panel: bars represent means \pm S.E. of the GHR abundance. Bars with different letters differ at $P<0 \cdot 05$.

recovery of GHR abundance occurs in liver as early as 10 days after parturition.

In cattle, the promoter of the GHR gene responsible for synthesis of the GHR1A transcript is stimulated by the liver-enriched transcription factor HNF4 (Jiang \& Lucy 2001a). To analyze changes in HNF4 abundance, liver extracts were resolved by SDS-PAGE, and membranes were probed with an antiserum raised against human HNF4 (Fig. 5). This antibody detected a doublet of the correct size $(\sim 55 \mathrm{kDa})$ in bovine extracts and in extracts prepared from 293 cells transfected with an HNF4 expression vector (293 HNF4; Fig 5A). This signal was specific, as shown by loss of the $55 \mathrm{kDa}$ signal in bovine liver and 293 HNF4 cells when probing was performed in the presence of the HNF4 peptide used in immunization (Fig. 5A). Hepatic HNF4 abundance, however, was constant during the transition period, including day +3 , when abundance of the GHR1A mRNA was reduced (Fig. 5B). Therefore, the periparturient reduction in GHR1A is not caused by a deficit in liver HNF4.

GHR is not regulated in skeletal muscle during the transition period

Finally, we asked whether parturition affected GHR abundance in skeletal muscle where GHR1A is absent 
(A)
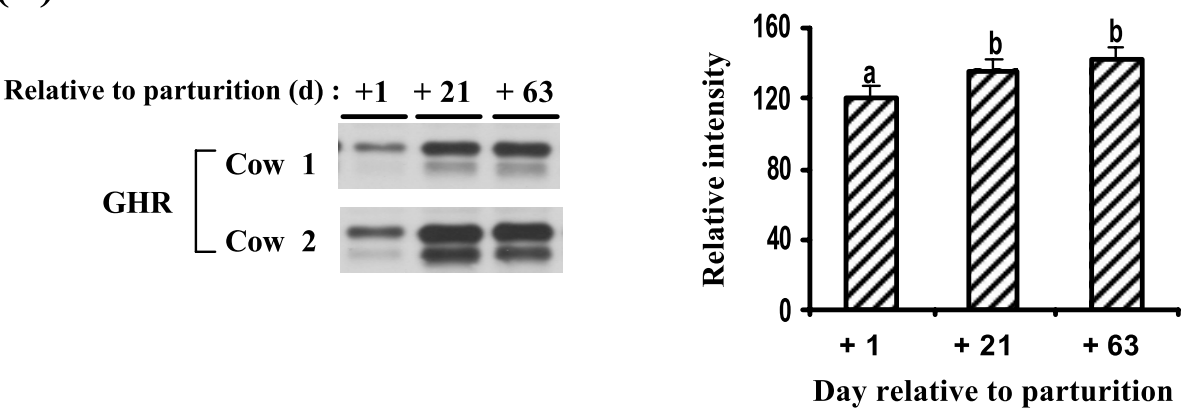

(B)
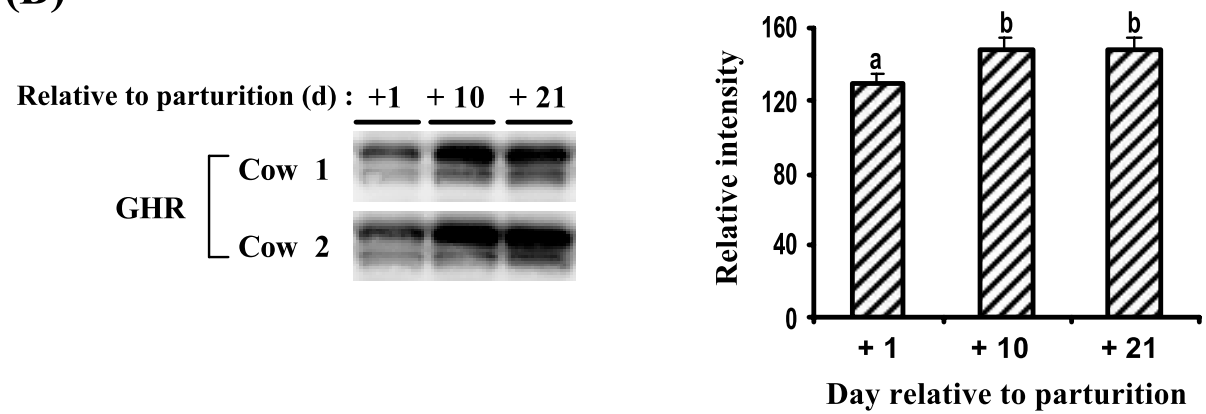

Figure 4 Recovery of hepatic GHR abundance after parturition. Hepatic GHR abundance was measured in a first group of six cows on days $+1,+21$ and +63 (relative to parturition on day 0 , panel A) and in a second group of 8 cows on days $+1,+10$ and +21 (panel B). GHR abundance was analyzed in $35 \mu \mathrm{g}$ of total cellular lysates by Western immunoblotting. For each group of cows, data from two representative cows are shown on the left, and bars representing means \pm S.E. of the GHR abundance are shown on the right. Bars with different letters differ at $P<0 \cdot 05$.

(Lucy et al. 2001). GHR gene expression and GHR protein abundance were essentially equal on days $-35,+3$ and +56 (relative to parturition on day 0) (Fig. 6). Overall, these results are consistent with the maintenance of $\mathrm{GH}$ responsiveness in skeletal muscle during the periparturient period.

\section{Discussion}

In mature animals, plasma IGF-I is synthesized primarily in the liver, where transcription of the gene is regulated positively by GH (Le Roith et al. 2001). Therefore, efforts to understand the basis for depressed levels of circulating IGF-I during the periparturient period have focused on the regulation of GHR expression in the liver. In well-fed cattle, the liver contains three major classes of GHR transcripts, referred to as GHR1A, GHR1B and GHR1C, accounting respectively for $\sim 50 \%, 35 \%$ and $15 \%$ of total GHR mRNA (Kobayashi et al. 1999, Jiang \& Lucy 2001a, Lucy et al. 2001). In a previous study using nulliparous dairy cows, parturition caused coincidental reductions in
GHR1A and indices of hepatic IGF-I synthesis (that is, IGF-I mRNA and plasma IGF-I) (Kobayashi et al. 1999). These data suggested a model whereby reduced abundance of the GHR limits GH activation of IGF-I gene transcription.

An important piece of information that has been missing in support of this model is direct measurement of hepatic GHR abundance in periparturient cows. Such data are needed because extrapolating GHR abundance from gene expression data is not simple. This is because experiments performed with reticulocyte extracts suggest that each class of GHR transcript is translated with different efficiency (Jiang \& Lucy 2001a). Moreover, the non-GHR1A transcripts account for $\sim 50 \%$ of total GHR mRNA in prepartum liver, and they are not regulated by parturition (Kobayashi et al. 1999). To clarify this issue, we performed direct measurements of GHR protein in the liver of mature, periparturient dairy cows. As expected, parturition caused a reduction in the hepatic abundance of GHR1A and IGF-I mRNA and in plasma IGF-I. More importantly, our data show that GHR protein abundance is reduced at parturition when GHR $1 \mathrm{~A}$ abundance declines, but recovers after 8 weeks of lactation when 
(A)

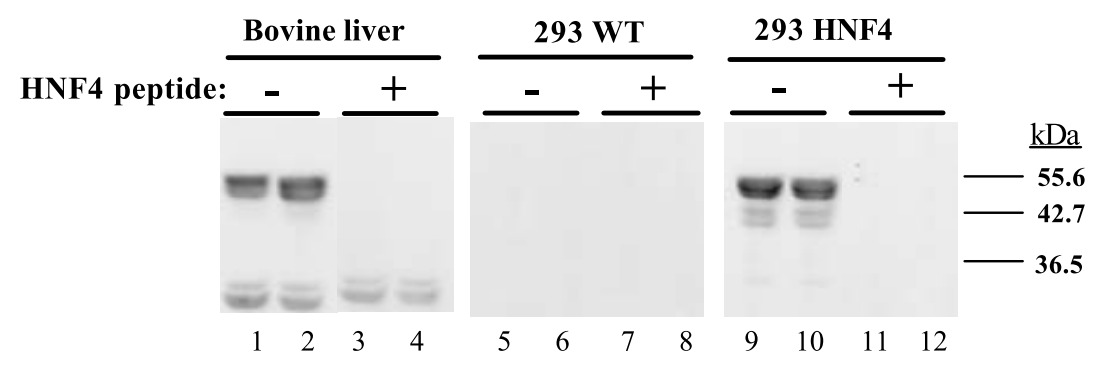

(B)

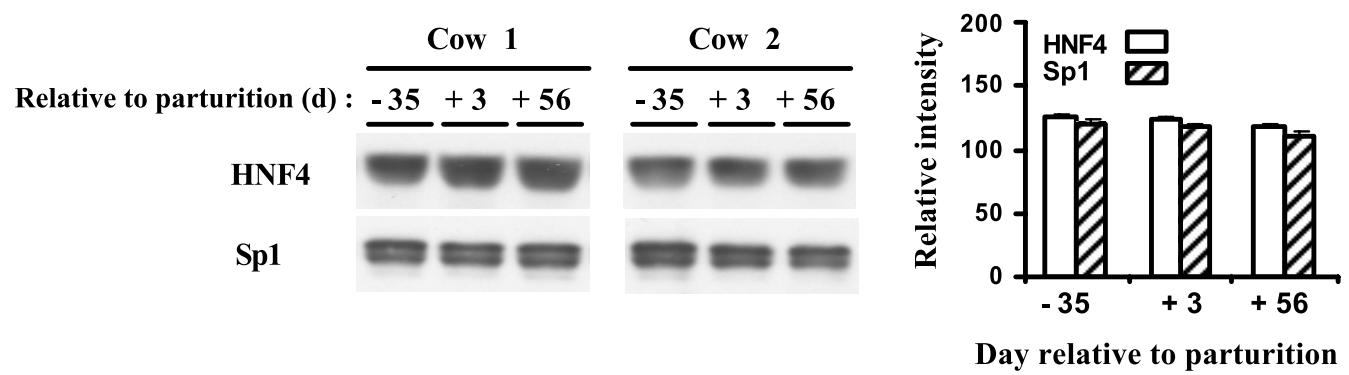

Figure 5 Hepatic abundance of HNF4 during the periparturient period. (A) Anti-HNF4 antibody detects the bovine HNF4. Total protein lysates were prepared from bovine liver, wild-type 293 cells (293 WT) or 293 cells transfected with the HNF4 CDNA (293 HNF4). Protein lysates $(50 \mu \mathrm{g})$ were resolved by SDS-PAGE and blotted onto nitrocellulose membranes. Western immunoblotting was performed in the absence $(-)$ or presence $(+)$ of $0.5 \mu \mathrm{g} / \mathrm{ml}$ of HNF4 peptide used in the immunization (amino acid residues 455-456 of human HNF4, Genka Biotechnology). The position of protein MW markers is shown on the right. (B) Hepatic abundance of HNF4 during the periparturient period. Four multiparous dairy cows were studied on days $-35,+3$ and +56 (relative to parturition on day 0). Left panel: total protein lysates $(35 \mu \mathrm{g})$ were resolved by SDS-PAGE and blotted onto nitrocellulose membranes. HNF4 was detected by immunoblotting analysis. As an additional control for equality of loading, blots were reprobed with anti-Sp1 antibodies detecting proteins of $\sim 95$ and $106 \mathrm{kDa}$ in bovine extracts (Wheeler et al. 1997). Data from two representative cows are shown. Right panel: bars represent means \pm S.E. of HNF4 or Sp1 abundance.

GHR1A is normalized. Additional measurements of GHR protein indicate that this recovery is rapid and detectable as early as day 10 of lactation.

Our data suggest that reduced GHR1A abundance is partly responsible for the decline of GHR abundance in periparturient liver. Factors responsible for reduced abundance of the GHR protein and GHR1A transcript remain uncertain in dairy cows, but could include the energy deficit and the hypoinsulinemia that develops around the time of parturition (Bell 1995, Block et al. 2001). Consistent with this idea, undernutrition results in decreased hepatic GH binding in growing ruminants (Breier et al. 1988, Bass et al. 1991). Moreover, physiological elevation of plasma insulin in early lactating dairy cows increases hepatic GHR1A abundance (Rhoads et al. 2002, Butler et al. 2003). Positive effects of insulin on GHR protein abundance have not been reported in lactating dairy cows, but they have been observed in rat liver and in the human cell line HuH7 (Baxter et al. 1980, Leung et al. 2000).

One primary factor known to stimulate the synthesis of the GHR1A is the liver-enriched transcription factor HNF4 (Jiang \& Lucy 2001b). HNF4 does so by binding to a specific cis-element in the proximal region of the GHR promoter responsible for GHR1A synthesis (Jiang \& Lucy 2001b). Interestingly, in rat liver, administration of the endotoxin lipopolysaccharide causes reductions in HNF4 abundance and GHR binding (Defalque et al. 1999, Wang et al. 2001). However, our data show that hepatic HNF4 abundance remained steady at parturition when GHR1A abundance is reduced, indicating that a deficit in HNF4 is not responsible for decreased GHR1A synthesis in periparturient dairy cows. HNF4 could still be causallyinvolved if parturition induced post-translational 
(A)

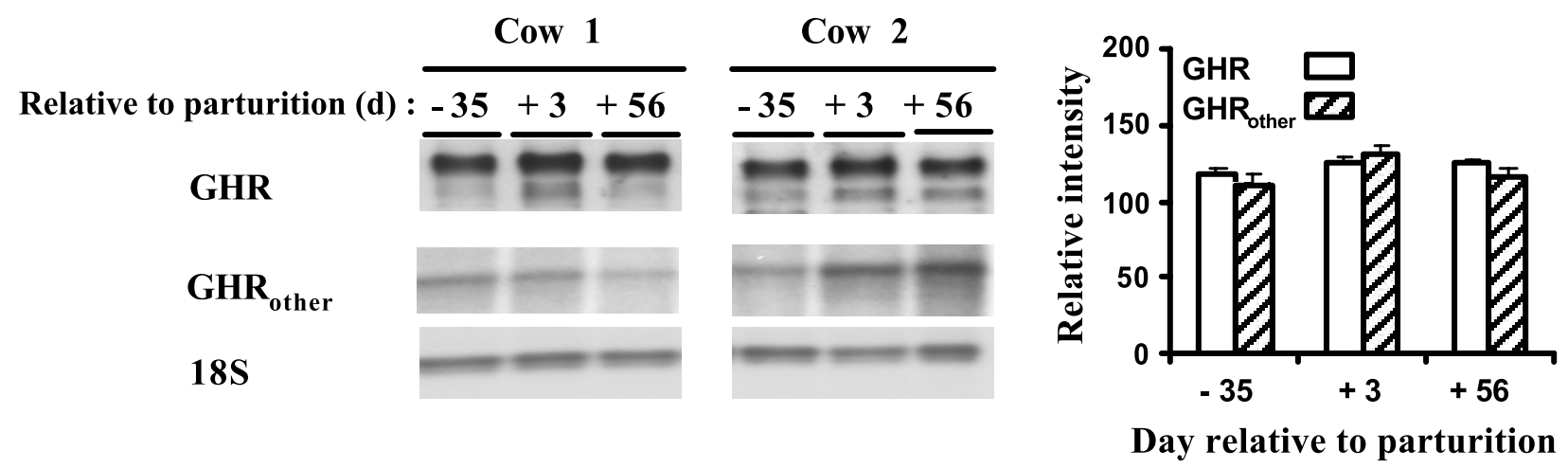

Figure 6 Expression of the GHR in skeletal muscle during the periparturient period. Four multiparous dairy cows were studied on days $-35,+3$ and +56 (relative to parturition on day 0). Abundance of the GHR protein (GHR) was measured in total protein lysates $(35 \mu \mathrm{g}$ ) by Western immunoblotting as described in Fig. 3. Abundance of the GHR mRNA $\left(\mathrm{GHR}_{\text {other }}\right)$ was measured in $10 \mu \mathrm{g}$ of total RNA by RPA. Left panel: data from two representative cows are shown. Right panel: bars represent means \pm S.E. of the GHR and GHR other $_{\text {signals. }}$

modifications that reduced its DNA binding ability (Viollet et al. 1997).

To our knowledge, the effects of parturition on GHR mRNA and GHR protein have not been reported in nonhepatic tissues of dairy cattle. We chose to focus on skeletal muscle, where the elevated GH of early lactation is thought to attenuate glucose uptake (Bauman \& Vernon 1993). This adaptation is important to increase the supply of glucose to the mammary gland. As in other extrahepatic tissues, GHR1A is absent in skeletal muscle, and GHR1B and GHR1C respectively account for $\sim 2 / 3$ and $1 / 3$ of total GHR mRNA (Jiang et al. 1999, Jiang \& Lucy 2001a). We found that both total GHR mRNA and GHR protein were maintained at parturition in skeletal muscle. Maintenance of GHR levels, however, does not necessarily guarantee normal GH responsiveness, as shown recently in fasted rat liver (Beauloye et al. 2002). Therefore, future studies are needed to show that the ability of $\mathrm{GH}$ to reduce skeletal muscle glucose uptake is maintained in periparturient dairy cows.

Bauman and coworkers (Bauman \& Vernon 1993) proposed a model of GH action in lactating dairy cows. According to this model, GH actions are reduced in liver during periods of severe undernutrition such as the periparturient period, limiting IGF-I production and its associated anabolic effects. In contrast, GH is thought to contribute to the maintenance of metabolic homeostasis by remaining fully effective in skeletal muscle and adipose tissue. Our data provide mechanistic elements to this model by showing that parturition causes a decrease in the abundance of the GHR in liver, but is without any effect in skeletal muscle. Finally, although not the focus of the present work, our results illustrate that hepatic GHR abundance and IGF-I production are not the only factors regulating plasma IGF-I during lactation. Specifically, plasma IGF-I failed to increase between parturition and day 56 of lactation even though hepatic abundance of the GHR and IGF-I mRNA had returned to precalving values. The simplest hypothesis to explain this failure is that early lactation alters other components of the circulating IGF complexes (that is, IGF-binding proteins) in such a way that the stability of IGF-I in plasma is decreased. This possibility needs to be addressed in future studies.

\section{Acknowledgements}

Jin Wook Kim was the recipient of a Korea Government Study-Abroad Scholarship. This work was supported by the Cornell University Agricultural Experimental Station, NIH grant DK51624 (Y R B) and NIH grant DK46395 (S J F). The authors thank Dr F N Sladek for providing the plasmid pcDNA3-1-rHNF4 $\alpha$, and G Bernal-Santos, Ramona Ehrhardt, Kathleen Ogborn, Mary Partridge and Michael Piepenbrink for help in conducting the animal phase of this work.

\section{References}

Bass JJ, Oldham JM, Hodgkinson SC, Fowke PJ, Sauerwein H, Molan P, Breier BH \& Gluckman PD 1991 Influence of nutrition and bovine growth hormone $(\mathrm{GH})$ on hepatic $\mathrm{GH}$ binding, insulin-like growth factor-I and growth of lambs. Journal of Endocrinology 128 181-186.

Bauman DE 2000 Regulation of nutrient partitioning during lactation: homeostasis and homeorhesis revisited. In Ruminant Physiology, Digestion, Metabolism, Growth and Reproduction. Proceedings of the 9th International Symposium on Ruminant Physiology, pp. 311-328. Ed PB Cronje. New York: CABI Publishing.

Bauman DE \& Vernon RG 1993 Effects of exogenous bovine somatotropin on lactation. Annual Review of Nutrition 13 437-461. 
Bauman DE, Peel CJ, Steinhour WD, Reynolds PJ, Tyrrell HF, Brown AC \& Haaland GL 1988 Effect of bovine somatotropin on metabolism of lactating dairy cows: influence on rates of irreversible loss and oxidation of glucose and nonesterified fatty acids. Journal of Nutrition 118 1031-1040.

Baxter RC, Bryson JM \& Turtle JR 1980 Somatogenic receptors of rat liver: regulation by insulin. Endocrinology 107 1176-1181.

Beauloye V, Willems B, de Coninck V, Frank SJ, Edery M \& Thissen JP 2002 Impairment of liver GH receptor signaling by fasting. Endocrinology 143 792-800.

Bell AW 1995 Regulation of organic nutrient metabolism during transition from late pregnancy to early lactation. Journal of Animal Science 73 2804-2819.

Bernal-Santos G, Perfield II JW, Barbano DM, Bauman DE \& Overton TR 2003 Production responses of dairy cows to dietary supplementation with conjugated linoleic acid (CLA) during the transition period and early lactation. Journal of Dairy Science $\mathbf{8 6}$ 3218-3228.

Block SS, Butler WR, Ehrhardt RA, Bell AW, Van Amburgh ME \& Boisclair YR 2001 Decreased concentration of plasma leptin in periparturient dairy cows is caused by negative energy balance. Journal of Endocrinology 171 339-348.

Boisclair YR, Brown AL, Casola S \& Rechler MM 1993 Three clustered Sp1 sites are required for efficient transcription of the TATA-less promoter of the gene for insulin-like growth factor-binding protein-2 from the rat. Journal of Biological Chemistry 268 24892-24901.

Boisclair YR, Bauman DE, Bell AW, Dunshea FR \& Harkins M 1994 Nutrient utilization and protein turnover in the hindlimb of cattle treated with bovine somatotropin. Journal of Nutrition 124 664-673.

Breier BH, Gluckman PD \& Bass JJ 1988 The somatotrophic axis in young steers: influence of nutritional status and oestradiol-17 beta on hepatic high- and low-affinity somatotrophic binding sites. Journal of Endocrinology 116 169-177.

Butler ST, Marr AL, Pelton SH, Radcliff RP, Lucy MC \& Butler WR 2003 Insulin restores GH responsiveness during lactation-induced negative energy balance in dairy cattle: effects on expression of IGF-I and GH receptor 1A. Journal of Endocrinology 176 205-217.

Cohick WS, Plaut K, Sechen SJ \& Bauman DE 1989 Temporal pattern of insulin-like growth factor-I response to exogenous bovine somatotropin in lactating cows. Domestic Animal Endocrinology 6 263-273.

Defalque D, Brandt N, Ketelslegers JM \& Thissen JP 1999 GH insensitivity induced by endotoxin injection is associated with decreased liver GH receptors. American Journal of Physiology 276 E565-572.

Elsasser TH, Sartin JL, McMahon C, Romo G, Fayer R, Kahl S \& Blagburn B 1998 Changes in somatotropic axis response and body composition during growth hormone administration in progressive cachectic parasitism. Domestic Animal Endocrinology 15 239-255.

Etherton TD \& Bauman DE 1998 Biology of somatotropin in growth and lactation of domestic animals. Physiological Reviews 78 745-761.

Herrington J \& Carter-Su C 2001 Signaling pathways activated by the growth hormone receptor. Trends in Endocrinology and Metabolism 12 252-257.

Jiang H \& Lucy MC 2001a Variants of the 5'-untranslated region of the bovine growth hormone receptor mRNA: isolation, expression and effects on translational efficiency. Gene $26545-53$.

Jiang H \& Lucy MC $2001 b$ Involvement of hepatocyte nuclear factor- 4 in the expression of the growth hormone receptor $1 \mathrm{~A}$ messenger ribonucleic acid in bovine liver. Molecular Endocrinology 15 1023-1034.

Jiang H, Okamura CS \& Lucy MC 1999 Isolation and characterization of a novel promoter for the bovine growth hormone receptor gene. Journal of Biological Chemistry 274 7893-7900.

Kobayashi Y, Boyd CK, Bracken CJ, Lamberson WR, Keisler DH \& Lucy MC 1999 Reduced growth hormone receptor (GHR) messenger ribonucleic acid in liver of periparturient cattle is caused by a specific down-regulation of GHR $1 \mathrm{~A}$ that is associated with decreased insulin-like growth factor I. Endocrinology 140 3947-3954.

Le Roith D, Bondy C, Yakar S, Liu JL \& Butler A 2001 The somatomedin hypothesis: 2001. Endocrine Review 22 53-74.

Leung KC, Doyle N, Ballesteros M, Waters MJ \& Ho KK 2000 Insulin regulation of human hepatic growth hormone receptors: divergent effects on biosynthesis and surface translocation. Journal of Clinical Endocrinology and Metabolism 85 4712-4720.

Lucy MC, Jiang H \& Kobayashi Y 2001 Changes in the somatotrophic axis associated with the initiation of lactation. Journal of Dairy Science 84 (E. Suppl) E113-119 [The paper is available at www.adsa.org/jds/abs/2001/jds_es113.htm].

Moloney AP, Beermann DH, Gerrard D, Robinson TF \& Finnerty KD 1998 Temporal change in skeletal muscle IGF-I mRNA abundance and nitrogen metabolism responses to abomasal casein infusion in steers. Journal of Animal Science 76 1380-1388.

NRC 2001 Nutrient Requirement of Dairy Cattle (7th rev. edn). Washington, DC: National Academy Press.

Okada S \& Kopchick JJ 2001 Biological effects of growth hormone and its antagonist. Trends in Molecular Medicine 7 126-132.

Rhoads RP, Greenwood PL, Bell AW \& Boisclair YR 2000 Organization and regulation of the gene encoding the sheep acid-labile subunit of the 150-kilodalton insulin-like growth factor-binding protein complex. Endocrinology 141 1425-1433.

Rhoads RP, Leury BJ, Baumgard LH, Block SS, Dwyer DA, Bell AW, Bauman DE \& Boisclair YR 2002 Effect of insulin on the GH-IGF-I axis in the periparturient dairy cow. Journal of Dairy Science 85 (Suppl 1) 195.

Sechen SJ, Dunshea FR \& Bauman DE 1990 Somatotropin in lactating cows: effect on response to epinephrine and insulin. American Journal of Physiology 258 E582-588.

Viollet B, Kahn A \& Raymondjean M 1997 Protein kinase A-dependent phosphorylation modulates DNA-binding activity of hepatocyte nuclear factor 4. Molecular and Cellular Biology 17 4208-4219.

Wang B, Cai SR, Gao C, Sladek FM \& Ponder KP 2001 Lipopolysaccharide results in a marked decrease in hepatocyte nuclear factor 4 alpha in rat liver. Hepatology 34 979-989.

Wang X, Xu B, Souza SC \& Kopchick JJ 1994 Growth hormone $(\mathrm{GH})$ induces tyrosine-phosphorylated proteins in mouse L cells that express recombinant GH receptors. PNAS 91 1391-1395.

Wang X, He K, Gerhart M, Huang Y, Jiang J, Paxton RJ, Yang S, Lu C, Menon RK, Black RA, Baumann G \& Frank SJ 2002 Metalloprotease-mediated GH receptor proteolysis and GHBP shedding. Determination of extracellular domain stem region cleavage site. Journal of Biological Chemistry 277 50510-50519.

Wheeler TT, Broadhurst MK, Rajan GH \& Wilkins RJ 1997 Differences in the abundance of nuclear proteins in the bovine mammary gland throughout the lactation and gestation cycles. Journal of Dairy Science 80 2011-2019.

Yi W, Kim SO, Jiang J, Park SH, Kraft AS, Waxman DJ \& Frank SJ 1996 Growth hormone receptor cytoplasmic domain differentially promotes tyrosine phosphorylation of signal transducers and activators of transcription $5 \mathrm{~b}$ and 3 by activated JAK2 kinase. Molecular Endocrinology 10 1425-1443.

Zhang Y, Guan R, Jiang J, Kopchick JJ, Black RA, Baumann G \& Frank SJ 2001 Growth hormone (GH)-induced dimerization inhibits phorbol ester-stimulated GH receptor proteolysis. Journal of Biological Chemistry 276 24565-24573.

Received 12 January 2004

Accepted 16 January 2004

Made available online as an

Accepted Preprint 27 January 2004 